\title{
Tekrarlayan İdrar Yolu Enfeksiyonu Geçiren Çocuklarda İşeme Bozukluklarının ve Standart Üroterapiye Yanıtın Değerlendirilmesi
}

\section{Evaluation of Voiding Dysfunction and Response to Standard Uroterapy in Children with Recurrent Urinary Tract Infections}

\author{
Birgül SAY ${ }^{1}$, Tuğrul TiRYAKi ${ }^{2}$, Sevilay KARAHAN ${ }^{3}$, Nilgün ÇAKAR ${ }^{4}$
}

\author{
1Sağlık Bilimleri Üniversitesi, Kocaeli Derince Eğitim Araştırma Hastanesi, Çocuk Sağlığı ve Hastalıkları Bölümü, Kocaeli, Türkiye \\ 2Sağllık Bilimleri Üniversitesi, Ankara Çocuk Sağlığı ve Hastalıkları Hematoloji ve Onkoloji Eğitim ve Araştırma Hastanesi, \\ Çocuk Ürolojisi ve Çocuk Cerrahisi Kliniği, Ankara, Türkiye \\ ${ }^{3}$ Hacettepe Üniversitesi, Biyoistatistik Bölümü, Ankara, Türkiye \\ ${ }^{4}$ Ankara Üniversitesi Tıp Fakültesi, Çocuk sağlığı ve Hastalıkları Anabilimdalı, Çocuk Nefroloji ve Romatoloji Bilim Dalı, Ankara Türkiye
}

\section{ÖZ}

Amaç: İdrar yolu enfeksiyonu (IYE) çocukluk döneminin en sık görülen bakteriyel enfeksiyonlarından biridir. Tekrarlayan IYE’larında en önemli risk faktörlerinden biri işeme bozukluklarıdır.Çalışmanın amaçları; nörolojik sorunu olmayan tekrarlayan IYE'nu olan çocuklarda işeme bozukluğu semptom skorunun (IBSS), işeme sonrası rezidü idrar hacminin, üroflovmetrik inceleme bulgularının değerlendirilmesi ve standart üroterapinin işeme bozukluğu semptomları üzerine etkisini değerlendirmektir.

Gereç ve Yöntemler: Çalışmaya Mart 2006 ile Haziran 2008 tarihleri arasında, yılda en az iki kez IYE geçiren, 4 yaş ve üzeri 98 hasta kabul edildi. Olgular İBSS, üroflovmetri ile değerlendirildi. İșeme bozukluğu saptanan 68 hastaya standart üroterapi uygulandı. Bu hastalar tedavinin 6. ayında işeme bozukluğu semptomları açısından tekrar değerlendirildi.

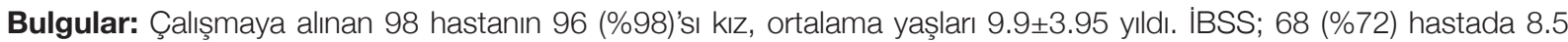
ve üstünde; 27 (\%28) hastada 8.5'dan küçük bulundu. Kabızlık 48 (\%49) hastada saptandı. Rezidü idrar hacmi 86 hastanın 46 (\%54)'ında 20 ml'nin üstünde bulundu. Üroflovmetri ile değerlendirilen 86 hastanın 40(\% 47)'ında çan, 21(\% 22)'inde stakkato, 20 (\%21)'inde fraksiyone, 4 (\%4)'ünde plato, 1 (\%1)'inde kule biçimli işeme eğrisi tespit edildi. IBSS skoru yüksek olan 68 olguya standart üroterapi tedavisi uygulandı. Altı ay sonunda İBS skoru 35 hastada $\leq 8.5$ saptandı. Enürezis diürnada \%68, enürezis noktürnada \%58, kesik kesik işemede \%84, idrarını yaptıktan kısa bir süre sonra tekrar idrara gitme şikayetinde \%91 oranında tam düzelme saptandı.

Sonuç: İBSS ve üroflovmetri işeme bozukluğunun tanımlanmasında pratik yöntemlerdir. Standart üroterapi, fonksiyonel işeme bozukluğu olan hastaların semptomlarının düzelmesinde etkin bir tedavi yöntemidir.

Anahtar Sözcükler: Çocuk, Prognoz ,Standart üroterapi, İdrar yolu enfeksiyonu, İseme bozukluğu

\begin{abstract}
Objective: Urinary tract infection (UTI) is one of the most common bacterial infections of children. The aims of this study were to evaluate voiding disfunction, and the effect of standart uroteraphy on the symptoms of disfunctional voiding in children with recurrent urinary tract infection.

Material and Methods: Between March 2006 and June 2008, 99 patients aged $\geq 4$ years who had UTI at least twice in a year were evaluated. The cases were assessed by uroflowmetry and dysfunctional voiding symptom score (DVSS). 68 patients with voiding dysfunction administered standard urotherapy. These patients were reevaluated for symptoms of voiding dysfunction at the end of six month - standart urotherapy.

Results: Ninety-six (98\%) of the 98 patients were female, mean age was $9.9 \pm 3.95$ years. DVSS was $\geq 8.5$ in 68 (72\%) patients. Constipation was found in 48 patients (49\%). 86 of 46 patients (54\%) had high residual urine volume (>20 ml). Uroflowmetric examinations were performed in 86 patients. 40 patients (47\%) had bell, 21 patients (22\%) had staccato, 20 patients (21\%) had fractioned, 1 patient (1\%) tower, 4 patients (4\%) had plateau shaped voiding curve. 68 patients with high DVSS underwent standard urotherapy. At the end of six month- standart urotherapy, the DVS score was $\leq 8.5$ in 35 patients. Complete recovery was found in $68 \%$ of diurnal enuresis, $58 \%$ in nocturnal enuresis, $84 \%$ in intermittent incontinence, $91 \%$ in feeling of incomplete urination and re-voiding.
\end{abstract}

Conclusion: DVSS and uroflowmetry are practical methods for defining voiding dysfunction. Standard urotherapy is an effective treatment technique for the recovery of symptoms of voiding dysfunction.

Key Words: Children, Prognosis, Standard urotherapy, Urinary tract infection, Voiding dysfunction

Yazışma Adresi / Correspondence Address:

\section{Birgül SAY}

Sağlık Bilimleri Üniversitesi, Kocaeli Derince Eğitim Araştırma Hastanesi,

Çocuk Sağlığı ve Hastalıkları Bölümü, Kocaeli,Türkiye

E-posta: birgullivasay@gmail.com
Geliş tarihi / Received : 09.10.2018 Kabul tarihi / Accepted : 22.11.2018 Elektronik yayın tarihi : :01.04.2019 Online published

DOI: 10.12956/tchd.547461 


\section{GiRiş}

Mesane ve bağırsak disfonksiyonu (MBD), temel olarak kabızlık ve / veya enkoprezis șeklinde dışkı eliminasyon sorunları ile birlikte alt üriner sistem semptomlarını (AÜSS) tanımlar (1). Tekrarlayan IYE ve vezikoureteral reflü (VUR)'lerde MBD görülme sıkliğı yüksektir. MBD'li çocuklarda pelvik taban kaslarının uygunsuz kasılması, mesanede trabekülasyon artışı, divertikül oluşumu, rezidü idrar miktarındaki artış ve işeme sırasındaki yüksek basınç enfeksiyona ve mesane epitelinde kan dolaşımını azaltarak iskemiye, mesanenin bakteriye karşı direncinin azalmasına neden olur (2). Fizyolojik olarak, bakteri laminer akışla üretradan atılı. Ancak işeme bozukluğu olanlarda türbülan akım oluşur ve bakteriler etkili bir şekilde uzaklaştırılamaz (3).

Mesane ve bağırsak disfonksiyonunda dizüri, aciliyet, sık idrar yapma, gündüz inkontinansı, enürezis, işemenin ertelenmesi ve idrar retansiyonu sık görülen AÜS belirtileridir. Aşırı aktif mesane, hipoaktif mesane ve disfonksiyonel işeme gibi ürolojik durumlar MBD'nin bir parçası olabilir $(4,5)$. Mesane ile bağırsak arasındaki embriyolojik, anatomik ve fonksiyonel etkileşimler iyi bilinmektedir. Genel olarak, artmış rektal dışkı yükü mesane boşalmasını ve / veya depolamayı etkileyebilir: 1) mekanik kompresyon nedeni ile mesane kapasitesinde azalma oluşur, sık işeme ve inkontinans gelișir ve, 2) mesanenin ve pelvik taban kaslarının fizyolojik sinir uyarımları değişir, giderek azalan işeme dürtüsü ve kronik mesane spazmları sonucunda yetersiz boşalma ve önemli miktarda rezidü idrar kalır $(6,7)$.

Isseme bozukluğu semptom skorlaması çocuklarda anormal işeme şekillerini nicel olarak değerlendirmek için kullanilır. İBSS, yalnızca tanı için bir araștırma yöntemi olmayıp, aynı zamanda invazif ișlemler yapmadan ișeme bozukluğu belirtilerinin nesnel bir değerlendirmesini de sağlar (8).

Basit ve non invaziv olması nedeniyle çocuklarda işemenin değerlendirilmesinde tarama testi olarak kabul gören üroflovmetri, ișeme bozukluğunun altında yatan nedeni, mesane kontraktilitesi ve mesane çıkıș direnci hakkında genel bilgi verir (9).

Bu çalışmanın amaçları tekrarlayan IYE'nu olan çocuklarda İBS'nin, ișeme sonrası rezidü idrar hacminin, üroflovmetrik inceleme bulgularının değerlendirilmesi ve standart üroterapinin ișeme bozukluğu semptomları üzerine etkisini değerlendirmektir.

\section{GEREÇ ve YÖNTEMLER}

Bu çalıșma 1 Mart 2006 - 30 Haziran 2008 tarihleri arasında Çocuk Nefroloji bölümünde izlenen 98 hasta ile yapıldı. Çalıșmaya alınan hastalar tekrarlayan IYE tanısı almış, normal üriner sistem anatomisine sahip, üriner sistem taş hastalığı, vezikoüretral reflüsü olmayan, normal 99 m Tc-DMSA böbrek sintigrafisi olan, aile onamı alınmış çocuklardı. Etik kurul onamı Ankara Çocuk Sağlı̆ı ve Hastalıkları Hematoloji ve Onkoloji
Eğitim ve Araştırma Hastanesi yerel etik kurulundan alındı.

İşlevsel işeme problemleri, ebeveynlerin de katılımı ile, IBSS anketine (Ek 1) göre değerlendirildi. Anket ve üroflovmetri sırasında hastaların IYE'ları yoktu. IBS skoru 8.5 ve üzeri ise, işeme bozukluğu için anlamlı kabul edildi. Hastaların üroflovmetrik değerlendirmeleri "MMS Libra Plus" cihazı ile yapıldı. Üroflovmetri ile idrar maksimum akış hızı ( $Q$ max), ortalama akış hızı, maksimum akış hızına ulaşma süresi, işenen idrar hacmi ve işeme zamanı değerlendirildi.

Isseme tipi International Children's Continence Society'ye (ICSS) göre tanımlanmış 5 akım tipi (çan, stakkato, fraksiyone, plato ve kule) şeklinde değerlendirildi. Ișeme hacmi 100 ml'den düşük olan hastalar istatistiksel değerlendirmeye dahil edilmedi.

ICCS'nin önerilerine göre gündüz yakınmaları esas alınarak işeme bozukluğu sınıflaması yapıldı (10).

\section{İşeme bozukluğu semptomları, tanımlar:}

Azalmış veya Artmış Işeme Sıklığı: Günde 8 veya daha fazla sayıda işemesi artmış işeme sıkığı, 3 veya daha az sayıda işemesi azalmış işeme sıklığı olarak tanımlanır.

İdrar kaçırma (inkontinans): İdrar kaçırmanın kontrol edilememesidir. Devamlı veya aralıkı olabilir.

Aciliyet (urgency): Acilen ișeme isteği anlamına gelmektedir. Bu çocuklar idrarını tutmak için bacaklarını birleştirirler.

Gece idrar yapma (Noktüri): 5 yaşından sonra uyurken yatak Islatmadır.

Ikınma: Çocuğun işemeye başlamak ve işemeyi sürdürmek için karın içi basıncını artırmasıdır.

Kesik Kesik Işeme: İşemenin sürekli akım şeklinde olmayıp, kesintili olmasıdir.

Disüri: Işeme sırasında yanma ve rahatsızlık şikayetidir.

Tam olarak boşalmama hissi / inkomplet boşalma hissi: İdrarın yetersiz boşaltılma duygusunu ifade eder.

Inkontinansı engellemeye yönelik kontrol manevraları: İșemeyi erteleme veya sıkıșma hissini basklama amacıyla yapılan hareketlerdir. Manevralar genel olarak ayak başparmağı üzerinde durma, bacaklarını çaprazlayarak üretrayı sıkışırmak (Vincent reveransı), ayak topuğunu perineye basacak şekilde yere çömelmedir.

Rezidü idrar hacmi, mesane tamamen boşaltıldıktan sonra pelvik USG ile ölçüldü. 4-6 yaş arasındaki çocuklar için 20 ml'nin üzerinde veya beklenen mesane kapasitesin \%10'nundan fazla rezidü idrar, $>6$ yaș için $>20 \mathrm{ml}$ veya beklenen mesane kapasitesinin \%15'inden fazla rezidü idrar patolojik olarak kabul edildi $(11,12)$.

İșeme bozukluğu olan 68 hastaya standart üroterapi tedavisi uygulandl. Bu tedavide hastalara iki saatte bir idrar yapması, 2-5 dakika sonra tekrar idrara çıkması (zamanlı ve ikili işeme), 
sağıkı işeme duruşunun kazandırıması, tutma hareketlerinden kaçınılması, kabızlığın önlenmesi şeklinde davranış değişikliğini içeren önerilerde bulunuldu. Tekrarlayan IYE tanısı ile izlenen hastaların hepsi antibiyotik profilaksisi ve overaktif mesane ve urge inkontinans tanısı alan 46 hasta da oxybutynin klorid tedavisi alıyordu. Standart üroterapi uygulanan hastalar 3 ay aralarla kontrole çağrıldı. 6. ay sonunda işeme bozukluğu semptomları açısından tekrar değerlendirildi. İileşmenin değerlendirilmesi: IBSS $\leq 8.5$ altında ise iyileşme, ebeveyn görüşüne göre; semptomlarda düzelme \%100 ise tam, \% 5099 ise kısmi iyileşme, <\%50 iyileşme olduysa yanıtsız olarak değerlendirildi.

\section{İstatistiksel Analiz}

Verilerin istatistiksel değerlendirilmesi 'Statistical Package for Social Sciences (SPSS 12.0) paket programı kullanılarak yapıldı. Kategorik değişkenler ise olgu sayısı ve (\%) olarak gösterildi. Tedavi öncesi ve sonrası durum Mc Nemar testi ile değerlendirildi. $\mathrm{P}<0.05$ olan sonuçlar istatistiksel olarak anlamlı kabul edildi.

\section{BULGULAR}

Çallşma grubuna alınan 98 hastanın yaş ortalaması $9.9 \pm 3$ yıl olup; 2 (\% 2)'i erkek, 96 (\%98)'ı kızdı. 95 olgu IBSS anketi ile değerlendirildi. 68 hastanın IBS skoru $\geq 8.5$ (\%72), 27 (\%28) hastanın $<8.5$ bulundu (Șekil 1). 3 hastanın ailesinden onam alınamadığından IBSS skorlaması yapılamadı. Hastaların 48 (\%49)'unda kabızılı saptandı. Tedavi öncesi işeme bozukluğu semptomları Tablo I'de verilmiștir. Rezidü idrar miktarı 86 hastanın 40 (\%46)'ında $20 \mathrm{ml}$ altında, 46 (\%54)'ında 20 ml'nin üzerinde bulundu.

Doksanbeş hastaya üroflovmetri yapıldı. Dokuz hastanın işeme hacmi 100ml'nin altında olduğundan istatistiksel değerlendirmeden çıkarıldı. Değerlendirmeye alınan 84 hastanın 40 (\%48)'inde normal çan tipi, 21(\%25)'inde stakkato tip, 20 (\%24)'inde fraksiyone tip, 4 (\%5)'ünde plato tip, 1 (\%1)'inde kule tipi işeme eğrisi saptandı. Rezidü idrar miktarı $20 \mathrm{ml}$ ve üzerinde olan 46 hastanın 22 (\%50)'inde çan tipi, 14 (\%30)'ünde stakkato, 8 (\%17)'inde fraksiyone tip işeme eğrisi saptandı. İşeme bozukluğu olan 68 hastanın 65 'inde standart üroterapiden 6 ay sonra işeme bozukluğu semptomları tekrar değerlendirildi. 35 hastada (\%54) tedavi sonrası IBS skoru $\leq 8.5$, 30 hastada (\%46) $\geq 8.5$ saptandı (Şekil 2). Tedavi sonrası IB semptomları Tablo Il'de görülmektedir. Enürezis diürnada \%68, enürezis noktürnada \%58, kesik kesik işemede \%84, idrarını yaptıktan kısa bir süre sonra tekrar idrara gitme şikayetinde \%91 oranında tam düzelme saptandı, Tedavi öncesine göre düzelme oranlarında istatistiksel olarak da anlamlı fark saptandı $(p<0.05)$ (Şekil 3).
Tablo I: Tedavi öncesi ișeme bozukluğu semptomları.

\begin{tabular}{|l|c|}
\hline İşeme bozukluğu semptomları & $\begin{array}{c}\text { Hasta sayısı } \\
\mathbf{n = 9 8}(\%)\end{array}$ \\
\hline Gece idrar yapma (Noktüri), * & $55(56)$ \\
\hline Azalmış veya artmış işeme sıklığı, * & $20(20)$ \\
\hline İşerken ıkınma, * & $7(7)$ \\
\hline Dizüri, * & $33(33)$ \\
\hline Kesik kesik işeme, * & $13(13)$ \\
\hline Tam olarak boşalmama hissi, * $^{*}$ & $12(12)$ \\
\hline Aciliyet, * & $59(60)$ \\
\hline İdrar tutma manevraları, * & $75(76)$ \\
\hline Gündüz idrar kaçırma, * & $63(64)$ \\
\hline
\end{tabular}

${ }^{*} n \%$

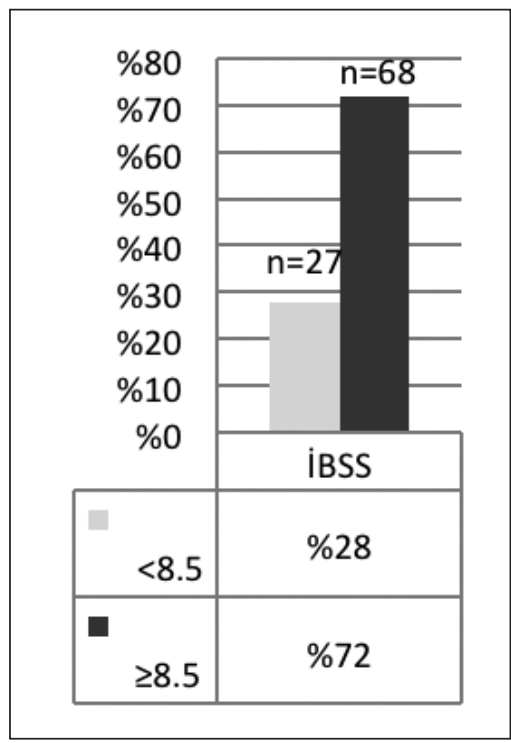

Şekil 1: Hastaların tedavi öncesi İBS Skorları (IBSS: Işeme bozukluğu semptomları).

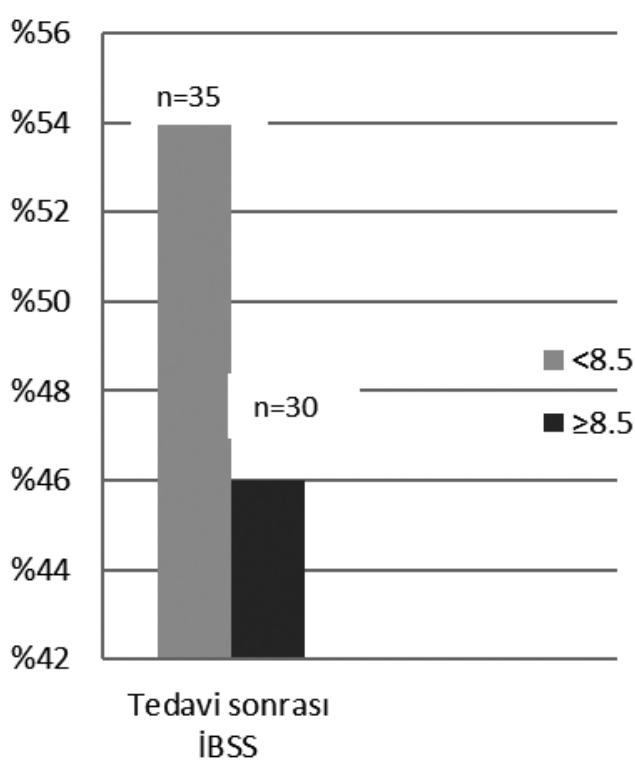

Şekil 2: Hastaların tedavi sonrası İBS Skorları (IBSS: İșeme bozukluğu semptomları). 


\section{TARTIŞMA}

Çocuklarda non-nörojenik alt üriner sistem disfonksiyonu (AÜSD) oldukça yaygındır ve alt üriner sistem semptomlarıın, idrar yolu enfeksiyonu ve vezikoüreteral reflünün altta yatan nedeni olarak önemlidir. Alt idrar yollarının fonksiyonel olgunlaşmasında gecikme, bağırsak disfonksiyonu, davranışsal ve psikolojik problemler alt üriner sistem disfonksiyonuna neden olabilir. 2005 ylında Akbal ve ark. (8) tarafından geliștirilen IBS skorlamasına göre 8.5 ve üzerinde puan alanlarda, skorlamanın işeme bozukluğunu göstermedeki özgüllüğünün ve duyarlıIğının \%90 olduğu bildirilmektedir. Hastalarımızın \%72'sinde IBS skorunun 8.5 ve üzerinde olması tekrarlayan IYY olan çocuklarda IBS skorlamasının ve işeme bozukluğu tedavisinin önemini destekleyen bir bulgudur.

Kabızlığın mesane disfonksiyonu olan çocuklarda \%30 ile \%88 oranlarında görüldüğü ve kabız olan çocukların kabız

Tablo II: Tedavi sonrası işeme bozukluğu semptomları.

\begin{tabular}{l|c}
\hline İşeme bozukluğu semptomları & $\begin{array}{c}\text { Hasta sayısı } \\
\mathbf{n = 6 5}(\%)\end{array}$ \\
\hline Gece idrar yapma (Noktüri), * & $23(35)$ \\
\hline Azalmış veya artmış işeme sıklığı, * & $18(28)$ \\
\hline İşerken ıkınma, * & $4(6)$ \\
\hline Dizüri, * & $23(35)$ \\
\hline Kesik kesik işeme, * & $2(3)$ \\
\hline Tam olarak boşalmama hissi, * & $1(1)$ \\
\hline Aciliyet, * & $20(30)$ \\
\hline İdrar tutma manevraları, * & $28(43)$ \\
\hline Gündüz idrar kaçırma, * & $20(30)$ \\
\hline
\end{tabular}

${ }^{*} n \%$ olmayanlara oranla 6.8 kat daha fazla AÜSD olma intimalinin olduğu bildirilmektedir (13). Kabızlıkta gerilmiş bağırsaklar mesaneyi sıkışırmakta, sfinkter ve pelvik taban kasları tarafından sağlanan işemenin normal periferik inhibisyonu ortadan kalkarak inkontinans gelişmektedir. Hastalarımızın tümünde kabızık oranı $\% 49$, IBSSS 8.5 ve üzerinde olanlarda ise $\% 48$ 'dir.

Gündüz idrar kaçırmanın en önemli nedeni işemenin son ana kadar ertelenmesidir. Idrar yolu enfeksiyonları da en sık nedenler arasındadır. Enürezis ile birlikte gündüz idrar kaçırmanın \%5060 oranında olduğu bildirilmektedir (14). Hastalarımızda gündüz idrar kaçırmanın \%68, enürezis noktürna ile birlikteliğinin ise \%56 oranında olduğu görüldü. İdrar tutma manevralarının, idrarın üretradan mesaneye yönlenmesine, rezidü idrarın ve IYE riskinin artmasına, mesaneye doğru süzülen idrarın mesane duvarının hipertrofisine ve detrüsörün perfüzyonunun azalmasına yol açtığı ileri sürülmektedir (15). Bununla birlikte, Gondim ve ark.nın (16) çallşmasında bu semptom ile tekrarlayan IYE arasında istatistiksel olarak anlamlı ilişki gösterilememiştir. Çalışmamızdaki hastaların \%76'sında idrar tutma manevraları tespit edilmiştir. İdrar yolu enfeksiyonları, travma, taş, yabancı cisimler ve mesane kapasitesinin azalması aciliyet hissine neden olur. Aciliyet hissinin inkontinans ile birlikteliğinin \%80, işeme sıklığında artış ile birlikteliğinin ise \%54 oranında olduğu, ve ürodinamik incelemede aşırı aktif mesane ve üretra-vezikal disfonksiyon bulgularını daha sık saptandığı bildirilmektedir (17). Çalışmamızda aciliyet hissi \%60, aciliyet hissinin inkontinans ile birlikteliği \%63, işeme sıklığında artış ile birlikteliği ise $\% 22$, oranında tespit edilmiştir.

Üroflovmetri testleri, işeme disfonksiyonunun altta yatan nedenleri hakkında ipuçları verir. Elde edilen sonuçlar, mesane kontraktilitesi ve mesane çııış direncinin özetidir (18). Stakkato işemede işemenin başlaması, detrusor kontraksiyonlarının

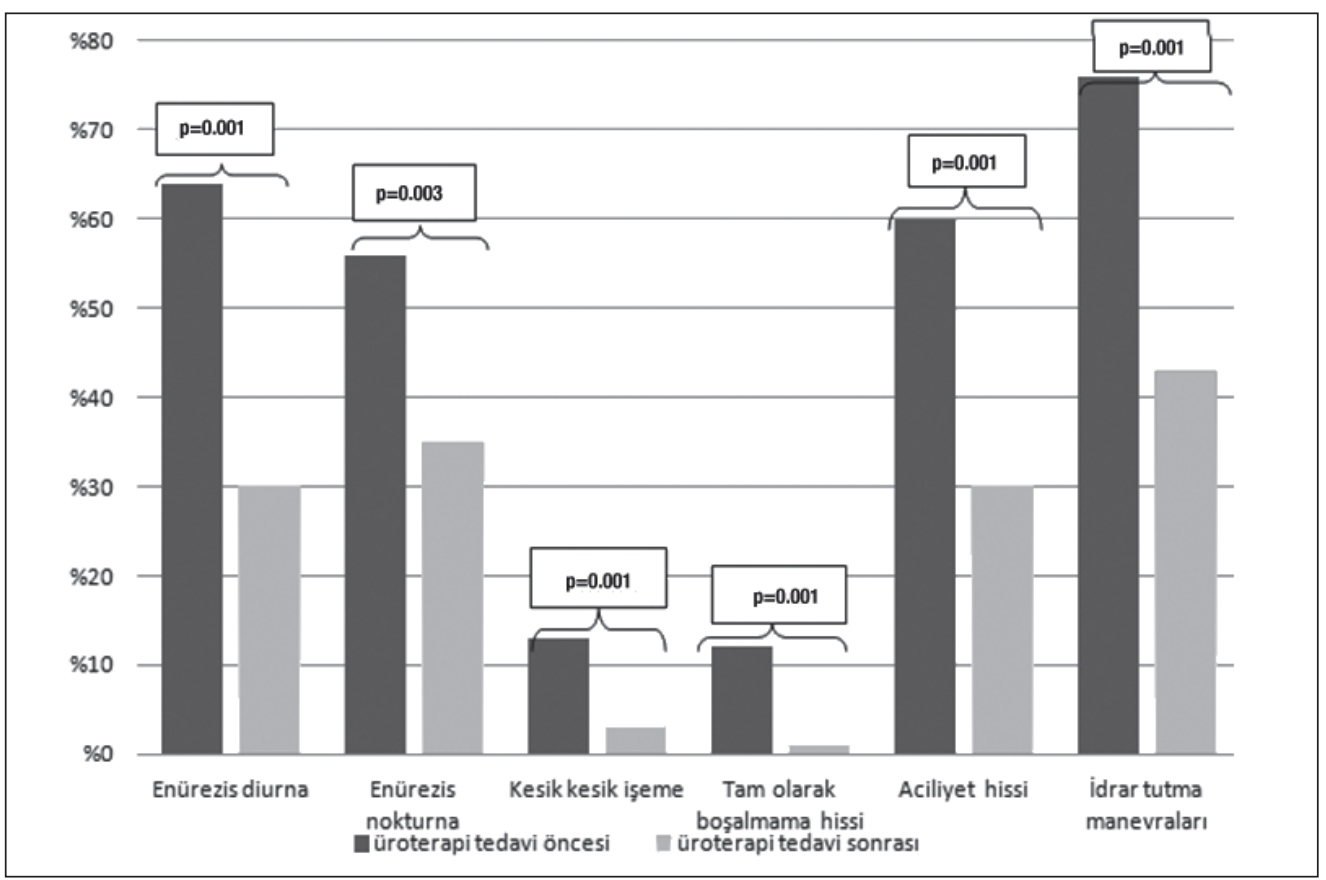

Şekil 3: Işeme bozukluğu olan hastaların standart üroterapi sonrası iyileşme oranları. 
başlamasından sonrasına ertelenir ve kesik kesik birkaç idrar fışkırması olur. Miksiyon sırasında ise pelvik taban kaslarının aktivitesinin artması kesintili işemeye, boşaltım basıncının ani yükselişlerine ve aynı anda idrar akışının paradoksal bir şekilde durmasına neden olur. İşeme uzun sürer ve genellikle tam boşaltım olmaz. Fraksiyone işemede ise detrusorun inaktivasyonu nedeni ile az ve kesintili bir boşaltım söz konusudur. Rezidü idrar önemli miktardadır. Hastalar seyrek ve daha çok ıkınma şeklinde idrar yapmaya çalışırlar. Bu da paradoksal bir etkiyle intravezikal basıncı artırır ve refleks mekanizmayla pelvik taban kas aktivitesinin artmasına neden olur (19). Üroflovmetri yapılan hastalarımızın 21 (\%22)'inde stakkato, 20 (\%21)'inde fraksiyone işeme saptandı. Sağlıklı çocuklarda işeme sonrası mesane tamamen boşalır. Tekrarlanan ölçümlerde 20 ml'den fazla rezidü idrar saptanması inkomplet boșalma veya anormal boşalma olarak tanımlanır $(20,21)$. Anormal işeme şekli, hiperaktif mesane kasılmaları, uygun olmayan pelvik taban kasılmaları ve eksternal sfinkter direnci, işeme basıncında artış ve yetersiz işemeye bağlı rezidüel idrar kalması gibi faktörlerle intravezikal basınç artmakta, mesane tam ve etkili boşalamamaktadır (22). Çalışmamızda rezidü idrar miktarı yüksek olan 46 hastanın \%30'unda stakkato, \%17'sinde fraksiyone, \%48'inde çan tipi işeme eğrisi vardı.

IYE'nin önlenmesinde mesanenin ve bağırsağın düzenli olarak boşaltıması önemlidir. Davranış tedavisi, çocuklarda fonksiyonel AÜSD'nun cerrahi dişı ve farmakolojik olmayan tedavisi olarak tanımlanmaktadır. ICCS'nin belirlediği kriterlere göre davranış tedavisine yanıtlar; ilk altı aylık süreçte semptomlarda 0-\% 49 oranında azalma olması cevapsızlık, \%50-89 azalma kısmi yanıt, \%90-100 azalma ise tam yanıt olarak değerlendirilmektedir (21).

Davranış tedavisi ile, işeme bozukluğu olan çocuklarda \%6080 oranında düzelme sağlandığı gösterilmiştir $(23,24)$. Bulum ve ark. (25), AUSD ve IYYE tanılı 4 yaș ve üzeri 228 olguda davranış tedavisi ile başarı oranının \%59 olduğunu bildirmişlerdir. Davranış tedavisinden ortalama 6 ay sonra hastalarımızın 35 (\%54)'inde İBS skoru $\leq 8.5$ saptandı. Enürezis diürnada \%68 (kısmi yanıt), enürezis noktürnada \%58 (kısmi yanıt), kesik kesik işemede \%84 (kısmi yanıt), idrarını yaptıktan kısa bir süre sonra tekrar idrara gitme yakınmasında \% 91 oranında (tam yanıt) iyileşme olduğu görüldü.

Sonuç olarak, işeme bozuklukların belirtileri, özellikle tekrarlayan IYE'nu olan 4 yaşın üstündeki kız çocuklarda sorgulanmalıdır. IBSS işeme bozukluklarının tanısında standardizasyonu sağlayan ve tedaviye yanıtının değerlendirmesinde klinikte kullanılan önemli objektif bir ölçektir. Davranış tedavisine yanıtlar ise tatmin edici düzeydedir.

\section{Finansal Kaynak}

Bu çalışma sırasında, yapılan araştırma konusu ile ilgili doğrudan bağlantısı bulunan herhangi bir ilaç firmasından, tıbbi alet, gereç ve malzeme sağlayan ve/veya üreten bir firma veya herhangi bir ticari firmadan, çalışmanın değerlendirme sürecinde, çalışma ile ilgili verilecek kararı olumsuz etkileyebilecek maddi ve/veya manevi herhangi bir destek alınmamıştır.

\section{Çıkar Çatışması}

Bu çalışma ile ilgili olarak yazarların ve/veya aile bireylerinin çıkar çatışması potansiyeli olabilecek bilimsel ve tıbbi komite üyeliği veya üyeleri ile ilişkisi, danışmanlık, bilirkişilik, herhangi bir firmada çalışma durumu, hissedarlık ve benzer durumları yoktur.

\section{KAYNAKLAR}

1. Santos JD, Lopes RI, Koyle MA. Bladder and bowel dysfunction in children: Anupdate on the diagnosis and treatment of a common, but under diagnosed pediatric problem. Can Urol Assoc J 2017;11:64-72.

2. Chrzan R, Klijn AJ, Vijverberg MA, Sikkel F, de Jong TP. Colonic washout enemas for persistent constipation in children with recurrent urinary tract infections based on dysfunctional voiding. Urology 2008;71: 607-10.

3. Hellström A, Hanson E, Hansson S, Hjälmås K, Jodal U. Association between urinary symptoms at 7 years old and previous urinary tract infection. Arch Dis Child 1991;66:232-4.

4. Kim JH, Lee JH, Jung AY, Lee JW. The prevalence and therapeutic effect of constipation in pediatric overactive bladder. Int Neurourol J 2011;15:206-10.

5. Lucanto C, Bauer SB, Hyman PE, Flores AF, Di Lorenzo C. Function of hollow viscera in children with constipation and voiding difficulties. Dig Dis Sci 2000;45:1274-80.

6. Kasirga E, Akil I, Yilmaz O, Polat M, Gözmen S, Egemen A. Evaluation of voiding dysfunctions in children with chronic functional constipation. Turk J Pediatr 2006;48: 340-3.

7. Averbeck MA, Madersbacher H. Constipation and LUTS - how do they affect each other? Int Braz J Urol 2011;37:16-28.

8. Akbal C, Genç, Y, Burgu, B, Ozden E, Tekgul S, Dysfunctıonal voiding and incontinence symptoms in pediatric population. J Urol 2005;173:969-73.

9. Kanematsu A, Johnin K, Yoshimura K, Okubo K, Aoki K, Watanabe $\mathrm{M}$, et al. Objective patterning of uroflowmetry curves in children with daytime and nighttime wetting. J Urol 2010;184:1674-9.

10. Austin PF, Bauer SB, Bower W, Chase J, Franco I, Hoebeke P, et al. The standardization of terminology of lower urinary tract function in children and adolescents: Update report from the Standardization Committee of the International Children's Continence Society. J Urol 2014;191:1863-5.

11. SJ Chang, LP Tsai, CK Hsu, SS Yang. Elevated postvoid residual urine volume predicting recurrence of urinary tract infections in toilet-trained children. Pediatr Nephrol 2015;30:1131-7.

12. Kibar $\mathrm{Y}$, Piskin M, Irkilata HC, Aydur E, Gok F, Dayanc M. Management of abnormal postvoid residual urine in children with dysfunctional voiding. Urology 2010;75:1472-5.

13. O'Regan S, Yazbeck S. Constipation: A cause of enuresis, urinary tract infection and vesico-ureteral reflux in children. Med Hypotheses 1985;17:409-13.

14. Robson WL, Leung AK, Bloom DA. Daytime wetting in childhood. Clin Pediatr 1996;35:91-8.

15. Nevéus T, Sillén U. Sillen. Lower urinary tract function in childhood; normal development and common functional disturbances. Acta Physiol (Oxf) 2013;207:85-92.

16. Gondim R, Azevedo R, Braga AANM, Veiga ML, Barroso U Jr. Risk factors for urinary tract infection in children with urinary urgency. Int Braz J Urol 2018;44:378-83.

17. Allen TD, Bright TC 3rd. Bright. Urodynamic patterns in children with dysfunctional voiding problems. J Urol 1978;119:247-49. 
18. Bartkowski DP, Doubrava RG. Ability of a normal dysfunctional voiding symptom score to predict uroflowmetry and external urinary sphincter electromyography patterns in children. J Urol 2004;172:1980-5.

19. Sinha S. Dysfunctional voiding: A review of the terminology, presentation, evaluation and management in children and adults. Indian J Urol 2011;27:437-47.

20. Chang SJ, Chiang IN, Hsieh CH, Lin CD, Yang SS. Age-and gender-specific nomograms for single and dual post-void residual urine in healthy children. Neurourol Urodyn 2013;32:1014-8.

21. Neveus T, Gontard A, Hoebeke P. The standartization of terminology of lower urinary tract function in children and adolescents: Report from the standartization committee of the International Children's Continence Society. J Urol 2006;176:314-24.

22. Koff SA, Wagner $\Pi$, Jayanthi VR. The relationship among dysfunctional Elimination syndromes, primary vesicoureteral reflux and urinary tract infections in children. J Urol 1998;160:1019-22.

23. Hodges SJ, Anthony EY. Occult mega rectum-A commonly unrecognized cause of enuresis. Urology 2012;79:421-4.

24. Hagstroem S, Rittig S, Kamperis K, Djurhuus JC. Timer watch assisted urotherapy in children: A randomized controlled trial. J Urol 2010;184:1482-8.

25. Bulum B, Özçakar ZB, Kavaz A, Hüseynova M, Ekim M, Yalçinkaya F. Lower urinary tract dysfunction is frequently seen in urinary tract infections in childrenand is often associated with reduced quality of life. Acta Paediatr 2014;103:454-8. 
Ek 1: Işeme Bozuklukları Semptom Skorlaması (IBSS)

Hastanın Adı Soyadı:

Dosya No:

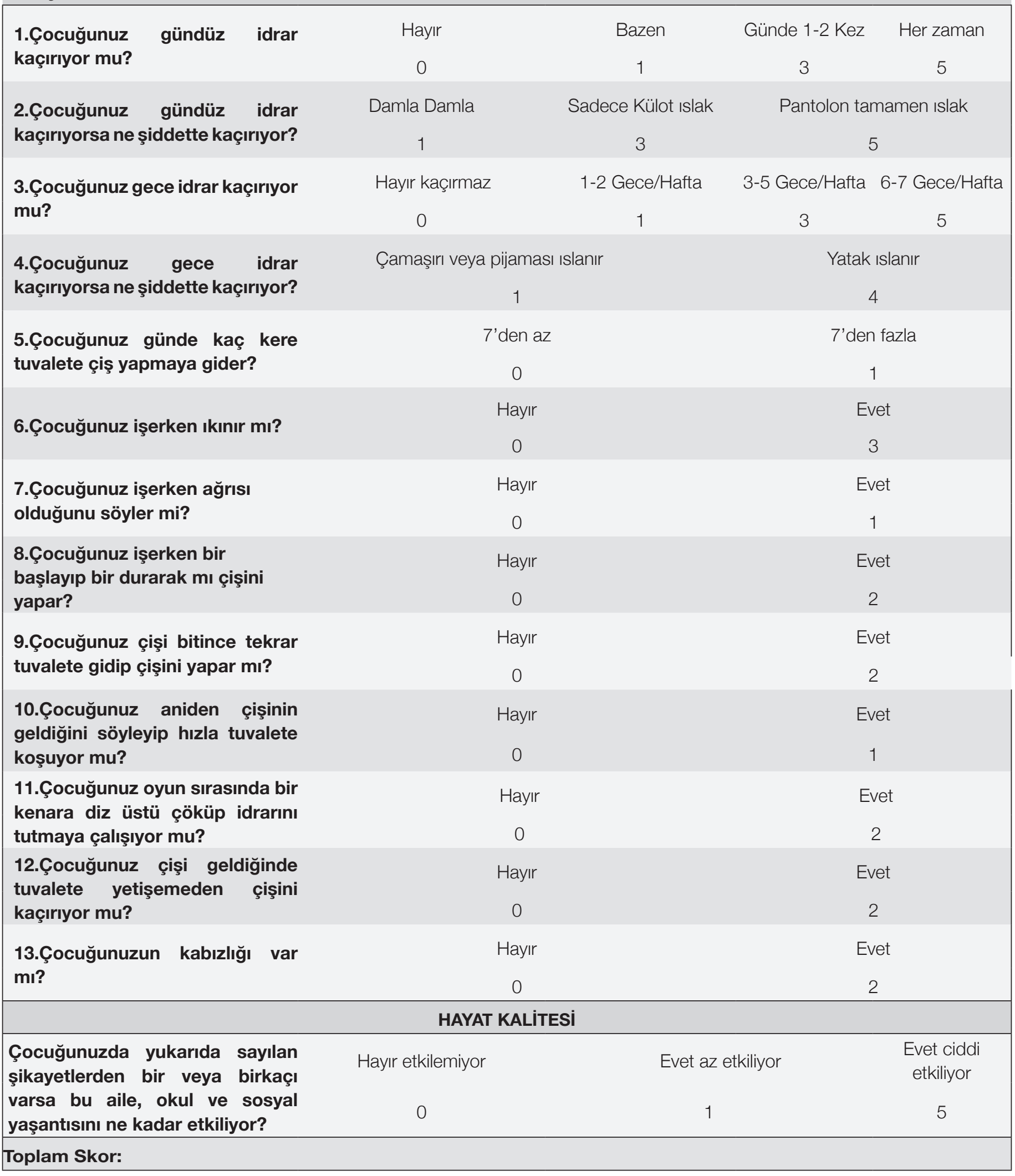

